\title{
GAS EXCHANGE PARAMETERS IN LEAVES AND EARS OF WINTER WHEAT Tricitum aestivum L. AND ITS PRODUCTIVITY UNDER FUNGICIDE CONTROL CONDITIONS
}

\author{
Joanna Katarzyna Jarmołkowicz, Jacek Olszewski \\ Department of Diagnostics and Plant Pathophysiology, University of Warmia and Mazury in Olsztyn, \\ Plac Łódzki 5, 10-727 Olsztyn, Poland \\ e-mail: jacek.olszewski@uwm.edu.pl
}

Received: 30.07 .2010

\section{Abstract}

A research experiment was conducted in which rates of photosynthesis and transpiration were measured in leaves and ears of two winter wheat varieties grown under fungicide control conditions and without fungicide control. A LI-COR 6400 portable gas exchange system was used in the investigations. In most cases the fungicide Juwel was shown to have no effect on the gas exchange processes, whereas the other of the fungicidal agents applied - Swing - significantly decreased the gas exchange rates measured.

Measurements of gas exchange parameters in ears showed that the intensity of gas exchange was low, in particular at the later stage of ear development. But the applied fungicide caused higher release of $\mathrm{CO}_{2}$ into the atmosphere than its uptake. Furthermore, the applied fungicides were found to significantly increase grain yield compared to the control treatment, both in the first and second year of the study.

Among the tested varieties, 'Nutka' was characterized by higher productivity, in spite of lower 1000 kernel weight. However, this cultivar developed longer ears with a larger amount of grains.

Key words: winter wheat, yield, fungicides, leaf and, ear photosynthesis transpiration

\section{INTRODUCTION}

Winter wheat is one of the most important plants cultivated in Poland. But if grown in high concentration, it is affected by adverse environmental factors; in particular, it is frequently infected by fungal pathogens. They inhibit the photosynthesis process by even as much as $75 \%$ due to the reduction of the assimilation area (Grzesiuk et al. 1999). Plant infection may also lead to the inhibition of water and nutrient transport from roots as well as to the outflow of assimilates accumulated in leaves. Furthermore, fungi produce toxins, enzymes, and growth regulators $(\mathrm{Ni}$ e $\mathrm{ls}$ e $\mathrm{n}$ and S meds ga a rd, 2003; Fris vad et al. 2008). As a result of substances released by pathogens and changes in the phytohormonal balance, disorders in the functioning of the plant first appear and then its death follows. Hence, the need to reduce the incidence of fungal pathogens seems to be unquestionable, and one of more effective methods is the application of fungicides. These chemical agents decrease plant infection and are characterized by a short residence time in soil, but they are also known to have an adverse phytotoxic effect, in particular on some physiological processes (Grzesiuk et al. 1999; Hurey and Śnieżko, 1986). Under the influence of fungicide application, necrosis may develop and there can also be disturbances in plant growth and development. Moreover, the growing period is extended, the rates of photosynthesis and stomatal transpiration are inhibited as well as cuticular transpiration increases.

The duration of photosynthesis is an important element that affects yield levels. Therefore, the photosynthetic activity of dying leaves can be taken over at the heading stage by ears, among others. Some researchers (Evans et al. 1972; Johnson and Mos s, 1976; B lum, 1985) even claim that during a period of drought stress ears play a more important role in carrying out photosynthesis than flag leaves. However, the study of Olszewski et al. (2008) showed that in these organs there was higher release of $\mathrm{CO}_{2}$ into the atmosphere than its assimilation. This phenomenon occurs during the daytime with the participation of photosynthetically active radiation (PAR) (K le c z k ow s ki et al. 1988) and is termed as photorespiration. Furthermore, some researchers ( $\mathrm{S} \mathrm{t}$ a r c k , 2002) claim that the proportion of organs other than leaves in total photosynthesis ranges from several to a dozen or so percent. 
Taking into account the above highlighted problems, a study was conducted to determine the effect of fungicide control on leaf and ear gas exchange parameters and yield of two winter wheat varieties.

\section{MATERIALS AND METHODS}

A two-factor experiment was set up in quadruplicate at the Bałcyny Production and Experimental Station in the period $2005-2007$. The experimental factors included two winter wheat Triticum aestivum L. 'Zyta' and 'Nutka', as well as two fungicide control levels:

I. Control (without fungicide protection)

II. Full fungicide protection:

Juwel TT 483 SE (active substance: epoxiconazole + kresoxim-methyl + fenpropimorph) - applied at the stem elongation stage

Swing Top 183 SC (active substance: dimoxystrobin + epoxiconazole) - applied at the beginning of heading.

The selection of the tested winter wheat cultivars results from their great popularity in field cultivation in north-eastern Poland and their high productivity. The variety 'Zyta' belongs to the so-called quality wheats, whereas 'Nutka' to bread wheats.

Photosynthesis and transpiration measurements were made using a LI-COR 6400 portable gas exchange system (DMP AG SA LTD) during the growing period. Photosynthesis and transpiration rates were determined at a constant $\mathrm{CO}_{2}$ concentration of $400 \mathrm{ppm}$ and a light intensity of $1000 \mu \mathrm{mol}$ $\times \mathrm{m}^{-2} \times \mathrm{s}^{-1}$. The source of photons was a LED light source emitting light with the main peak wavelength of $670 \mathrm{~nm}$ and the lower peak wavelength of 465 $\mathrm{nm}$. The measurements were made on the youngest fully developed leaves sampled from randomly selected plants from each plot. Starting from the heading stage, measurements were also performed on ears using the 6400-05 Conifer Chamber. Readings of gas exchange parameters were taken at several-day intervals, repeating each measurement five times. The study results show the average values for a particular plant growth stage (BBCH scale) as well as after the application of the fungicidal preparation. The figures presenting net leaf photosynthesis measurements give the amount of $\mathrm{CO}_{2}$ absorbed, expressed in $\mu \mathrm{mol} \times \mathrm{m}^{-2} \times \mathrm{s}^{-1}$, while in the case of ear gas exchange measurements the amount of $\mathrm{CO}_{2}$ absorbed or released is given, expressed in $\mu \mathrm{mol} \times \mathrm{m}^{-2} \times \mathrm{s}^{-1}$.

Statistical processing was performed using the multiple test that groups together means with similar values, classified into homogenous groups at a significance level of $\alpha=0.05$. The "STATISTICA" software package was used for calculations.

\section{RESULTS}

The rates of photosynthesis and transpiration in leaves of the investigated winter wheat varieties are shown in Figs 1-10. Both in the first and second year of the study, no significant changes in the values of the gas exchange parameters were found on the 7th day (BBCH 41 - 43) after the application of the fungicide Juwel TT 483 SE (Figs 1-2). Both tested wheat cultivars were characterized by similar values of the measured parameters. Moreover, in the second year of the study the values of photosynthesis and transpiration rates were found to be lower in all the treatments compared to the first experimental year. One should suppose that weather conditions affected the values of the plant gas exchange parameters. Measurements performed at later growth stages did not exhibit any effect of the applied fungicidal agents on leaf transpiration in the tested winter wheat varieties (Fig. 4). In the case of photosynthesis, its increase under the influence of the fungicide Juwel was found only in the first year of the study (Fig. 3). In addition, a decline in the rate of photosynthesis was demonstrated in the cv. Nutka in the first year and an increase in the second year of the experiment. Hence, it may be presumed that the cv. Nutka is relatively sensitive to changes in the rate of photosynthesis, depending on climate and weather patterns. Next measurements of gas exchange rates showed an increase only in photosynthesis in the Juwel fungicide treatments in the second year of the study (Fig. 5). On the other hand, the fungicidal agents did not differentiate the level of transpiration but its higher level was found in the second year of the study, which could be attributable to a large amount of rainfall, in particular in July (Fig. 6).

As a result of the application of the other fungicide, Swing Top $183 \mathrm{SC}$, at the beginning of the heading stage, both tested winter cultivars were characterized by similar levels of the gas exchange parameters on the 7th day (BBCH $57-59$ ) and the 21st day (BBCH 69-71) after its application (Figs 7-10). The applied fungicide significantly decreased the rate of leaf photosynthesis only in the first year of the study. The other parameters were at a similar level.

Rates of photosynthesis and transpiration in winter wheat ears were also investigated in the present experiment (Figs 11 and 14). The study results relating to the impact of the Juwel preparation are omitted in this paper due to a long period that passed from its application. The parameters measured on the 5th day after the application of the other fungicide Swing (BBCH $57-58)$ reached similar values in the case of the tested varieties and differences were insignificant both in the first and second year of the study. The application of the fungicide only resulted in a decrease in the rate of photosynthesis in the second year of the ex- 
Table 1

Some morphological features of winter wheat. Bałcyny Production and Experimental Station, 2005/07

\begin{tabular}{|c|c|c|c|c|}
\hline \multicolumn{2}{|c|}{ Treatments } & $\begin{array}{l}\text { Ear length } \\
{[\mathrm{cm}]}\end{array}$ & $\begin{array}{l}\text { Number of grains per ear } \\
{[\mathrm{pcs}]}\end{array}$ & $\begin{array}{c}\text { TGW } \\
{[\mathrm{g}]}\end{array}$ \\
\hline \multicolumn{5}{|c|}{ Mean values for cultivars: } \\
\hline \multicolumn{2}{|c|}{ Zyta } & $7.9 a^{*}$ & $37.8 \mathrm{a}$ & $49.9 \mathrm{~b}$ \\
\hline \multicolumn{2}{|c|}{ Nutka } & $8.2 b$ & $44.5 b$ & $47.4 \mathrm{a}$ \\
\hline \multicolumn{5}{|c|}{ Mean values for the fungicide treatment: } \\
\hline \multicolumn{2}{|c|}{ Control } & $8.1 \mathrm{a}$ & $40.9 \mathrm{a}$ & $47.6 \mathrm{a}$ \\
\hline \multicolumn{2}{|c|}{ Fungicide } & $8.1 \mathrm{a}$ & $41.3 \mathrm{a}$ & $49.7 b$ \\
\hline \multicolumn{5}{|c|}{ Mean values for treatment interaction: } \\
\hline \multirow{3}{*}{ Zyta } & Control & $8.0 \mathrm{ab}$ & $38.3 \mathrm{a}$ & $49.0 \mathrm{~b}$ \\
\hline & Fungicide & $7.8 \mathrm{a}$ & $37.2 \mathrm{a}$ & $50.7 \mathrm{c}$ \\
\hline & Control & $8.1 \mathrm{ab}$ & $43.5 b$ & $46.1 \mathrm{a}$ \\
\hline Nutka & Fungicide & $8.4 \mathrm{~b}$ & $45.4 \mathrm{~b}$ & $48.7 b$ \\
\hline
\end{tabular}

* homogenous groups according to Fisher's LSD test $(\alpha-=0.05)$

periment. The high level of rainfall in the second year of the study caused a higher rate of leaf transpiration and a lower level of photosynthesis. Intense transpiration could have limited $\mathrm{CO}_{2}$ assimilation in spite of wide opening of the stomata.

The next measurement of gas exchange parameters in ears was made at the grain ripening stage $(\mathrm{BBCH}$ 67-69; 71-73) (Figs 13 and 14). Measurements of photosynthesis in winter wheat ears showed that in the first year of the study, at the milk-ripe stage, there was higher $\mathrm{CO}_{2}$ release into the atmosphere than its uptake, which is indicated by negative values of the readings. In the next year of the experiment, investigations were carried out slightly earlier - at the watery ripe stage. A very low level of photosynthesis was then demonstrated in both tested varieties. But the other fungicide applied, Swing, caused a significant decrease in photosynthesis. In turn, the level of transpiration was higher in the variety 'Nut$\mathrm{ka}$ ' and in the treatments in which the fungicide had been applied. In addition, there was a significant increase in ear transpiration already from the milk ripe stage, which is associated with grain ripening.

Selected morphological features of the winter wheat varieties are presented in Table 1. Based on measurements of morphological traits of the tested cultivars, the 'Zyta' was found to be characterized by significantly higher 1000 grain weight. But the 'Nutka' developed significantly longer ears and a higher number of grains per ear. The applied fungicides had an effect only on thousand grain weight, causing its increase.

Both tested cultivars responded to the fungicides applied in a similar way. A positive impact of the fungicides was only found in the case of thousand grain weight. As far as the other morphological features are concerned, the values were similar when particular treatments are compared.

Winter wheat grain yields should be considered to be relatively high, in particular in the first year of the study (Fig. 15). Among the tested cultivars, yields of the 'Nutka' were higher both in the first and second year of the study, and the differences were statistically proven. The applied fungicides resulted in an increase in yield. Both cultivars responded with a significant increase in productivity to the fungicidal preparations applied, both in the first and second growing season.

\section{DISCUSSION}

The use of plant protection agents in crop cultivation is designed to reduce qualitative and economic losses to the minimum. The application of fungicides leads to decreased numbers of fungal pathogens in crops, therefore these chemical control agents indirectly cause an increase in yield obtained from chemically protected crops and contribute to their higher quality. Crop protection agents, in particular fungicides, allow the incidence of agricultural pests to be reduced significantly, but their application may also have negative effects on plants (R o ż e k and W n u k, 1994). Under the influence of fungicides, rates of photosynthesis and stomatal transpiration can be inhibited as well as cuticular transpiration increases. In the present study, only Swing caused a decrease in the rate of photosynthesis and only in the first year of the experiment. But the fungicidal preparation Juwel had a slightly stimulat- 


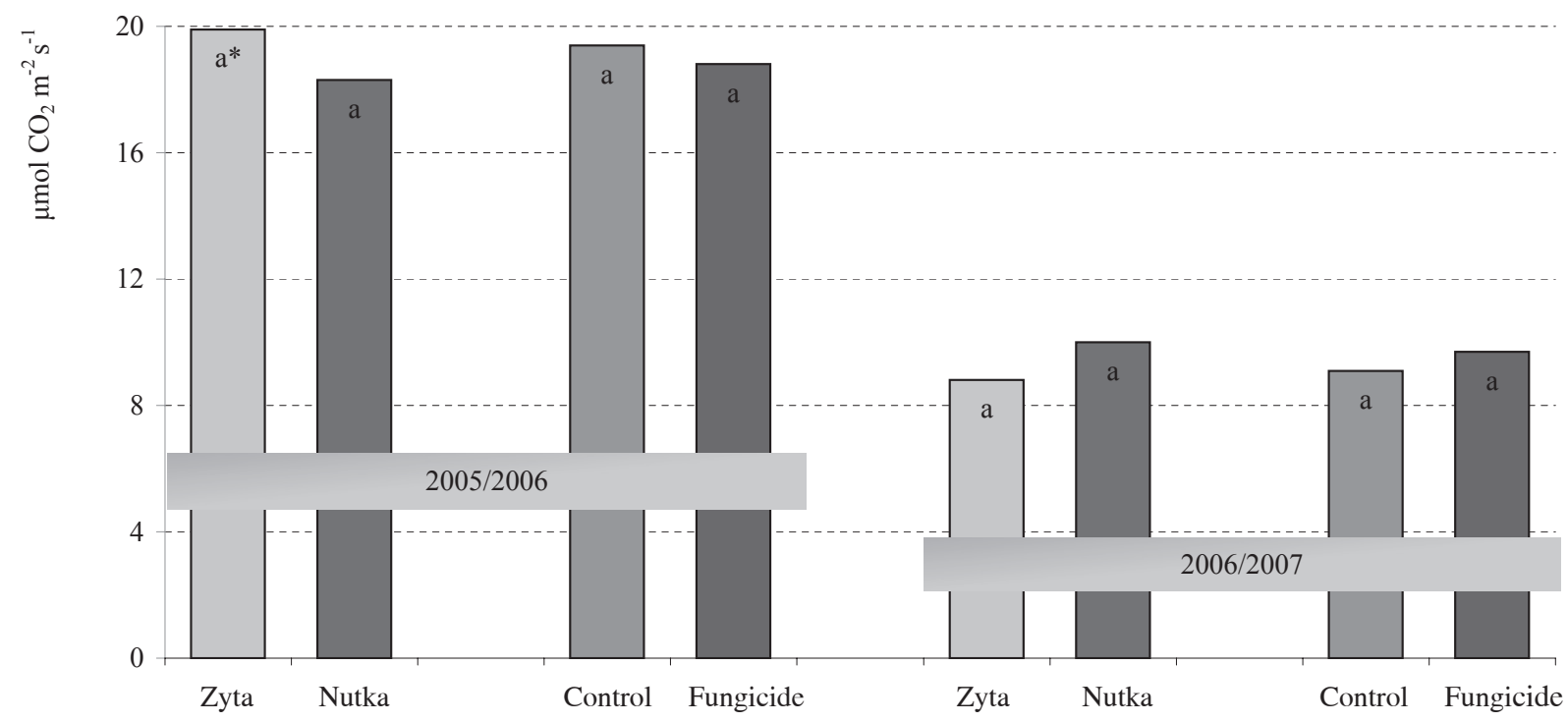

* homogenous groups according to Fisher's LSD test $(\alpha=0.05)$

Fig. 1. Winter wheat leaf photosynthesis 7 days after application of the fungicide Juwel (booting stage BBCH 41-43)

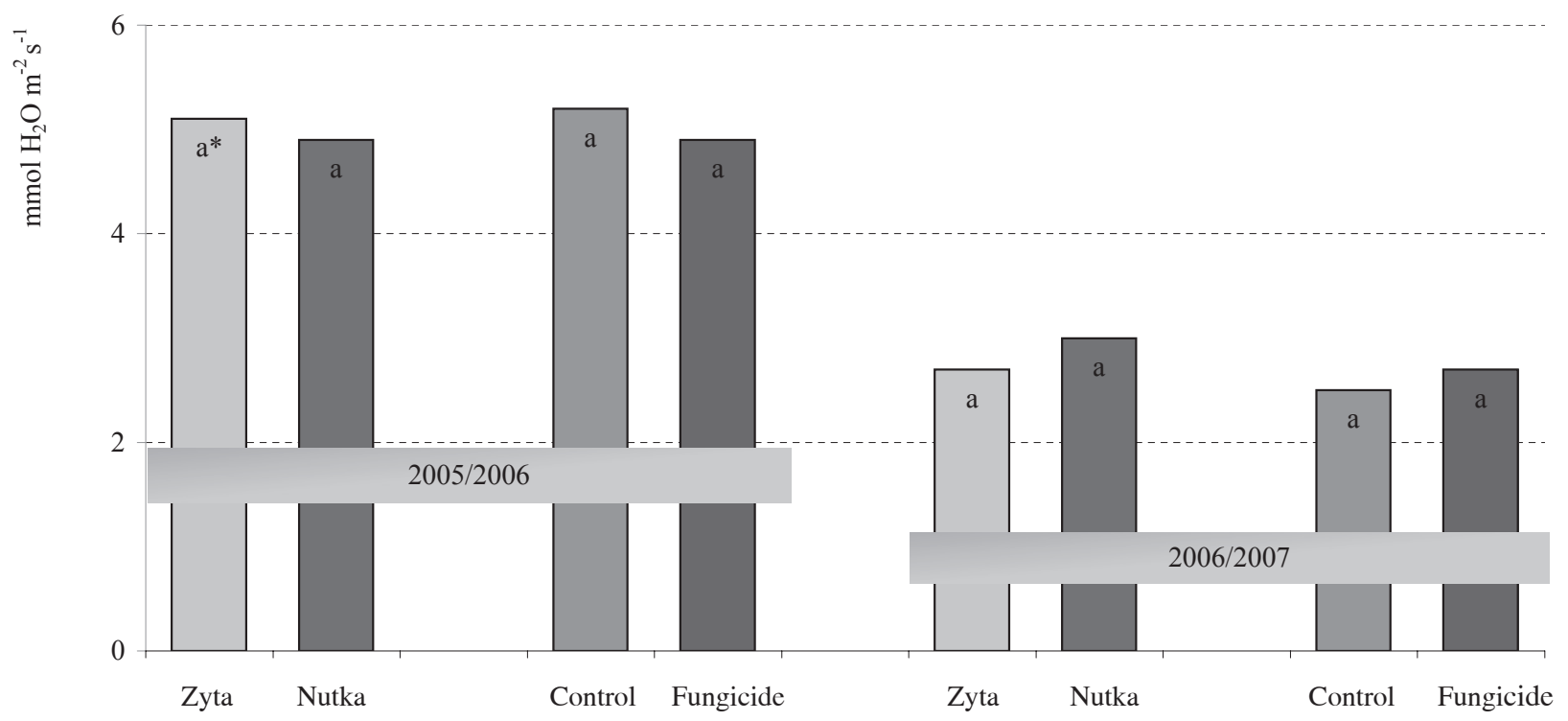

* homogenous groups according to Fisher's LSD test $(\alpha=0.05)$

Fig. 2. Winter wheat leaf transpiration 7 days after application of the fungicide Juwel (booting stage BBCH 41-43) 


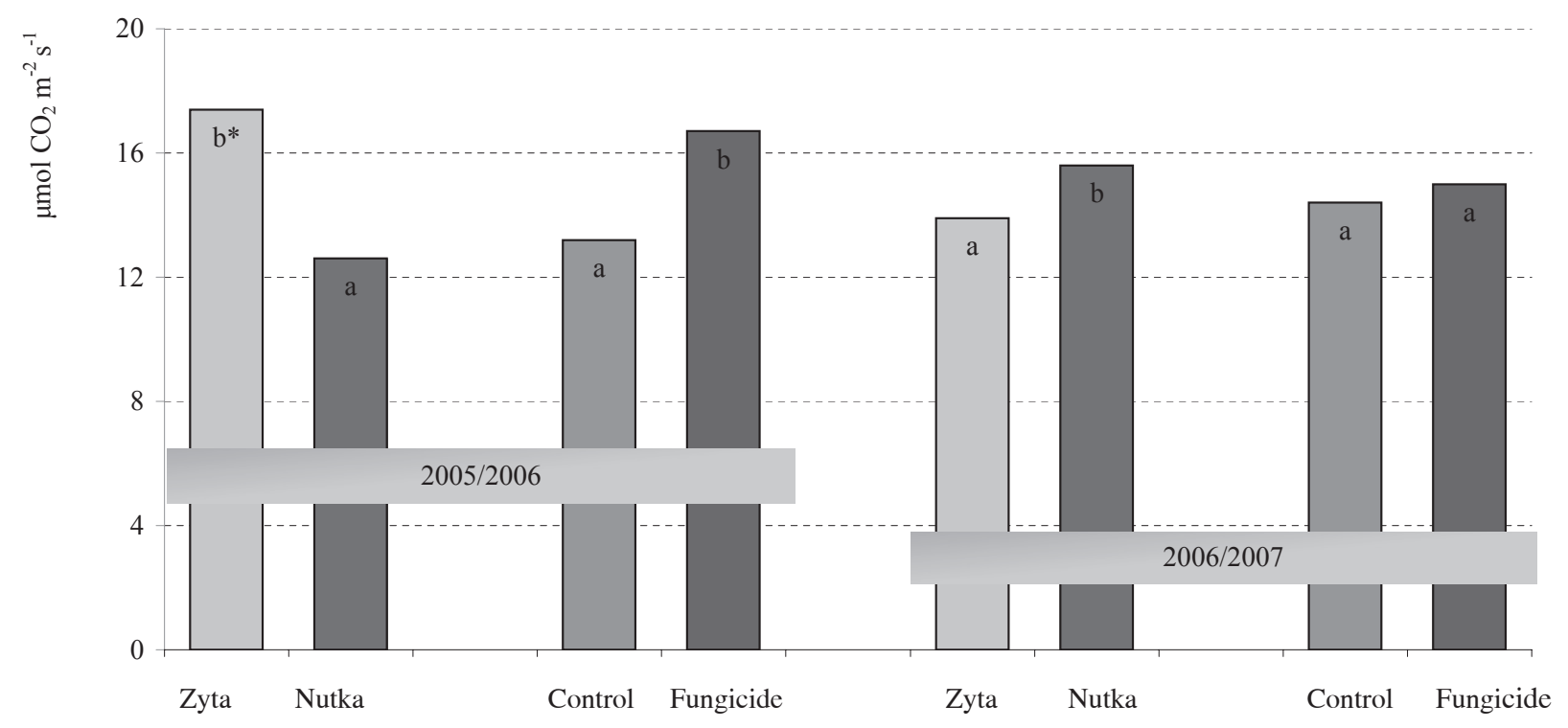

* homogenous groups according to Fisher's LSD test $(\alpha=0.05)$

Fig. 3. Winter wheat leaf photosynthesis 23 days after application of the fungicide Juwel (booting stage BBCH 45-49)

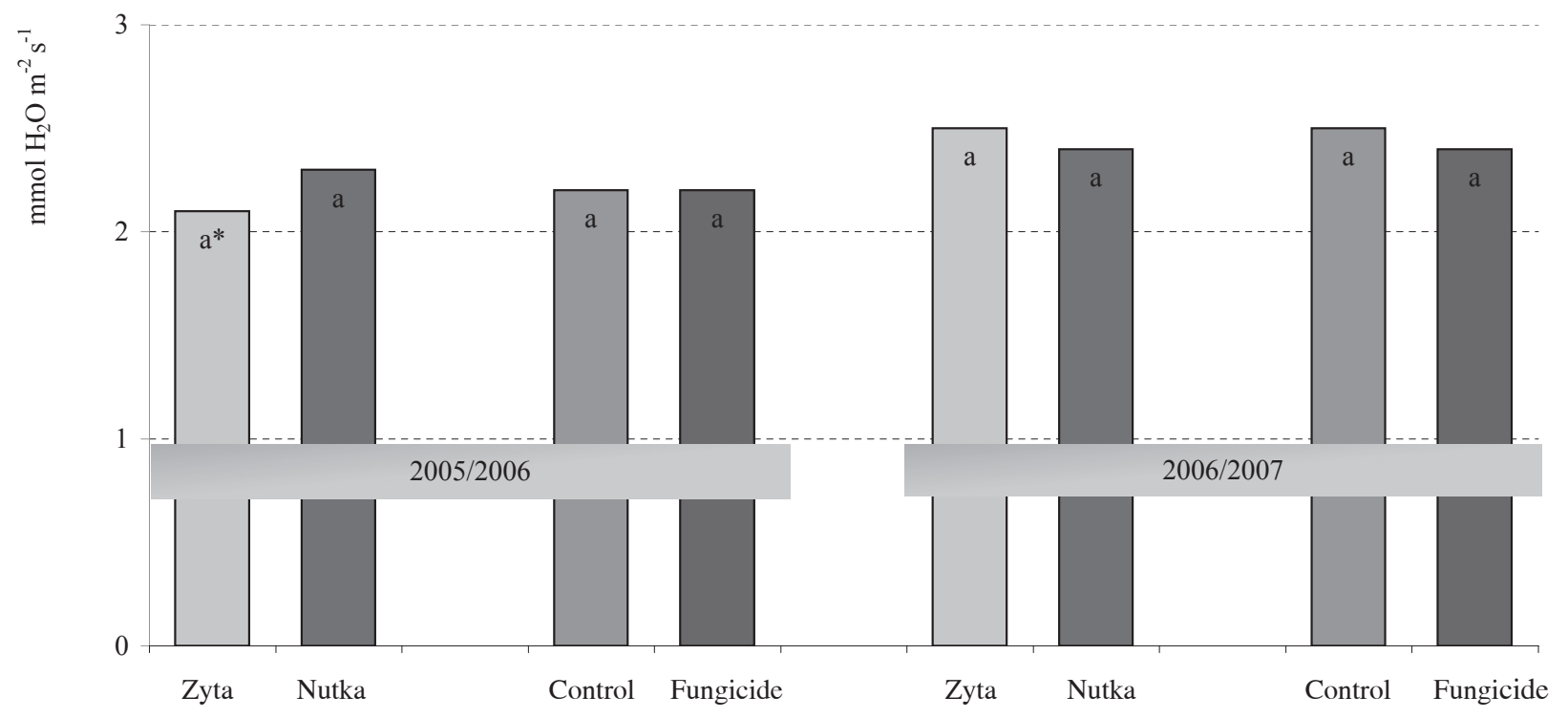

* homogenous groups according to Fisher's LSD test $(\alpha=0.05)$

Fig. 4. Winter wheat leaf transpiration 23 days after application of the fungicide Juwel (booting stage BBCH 45-49) 


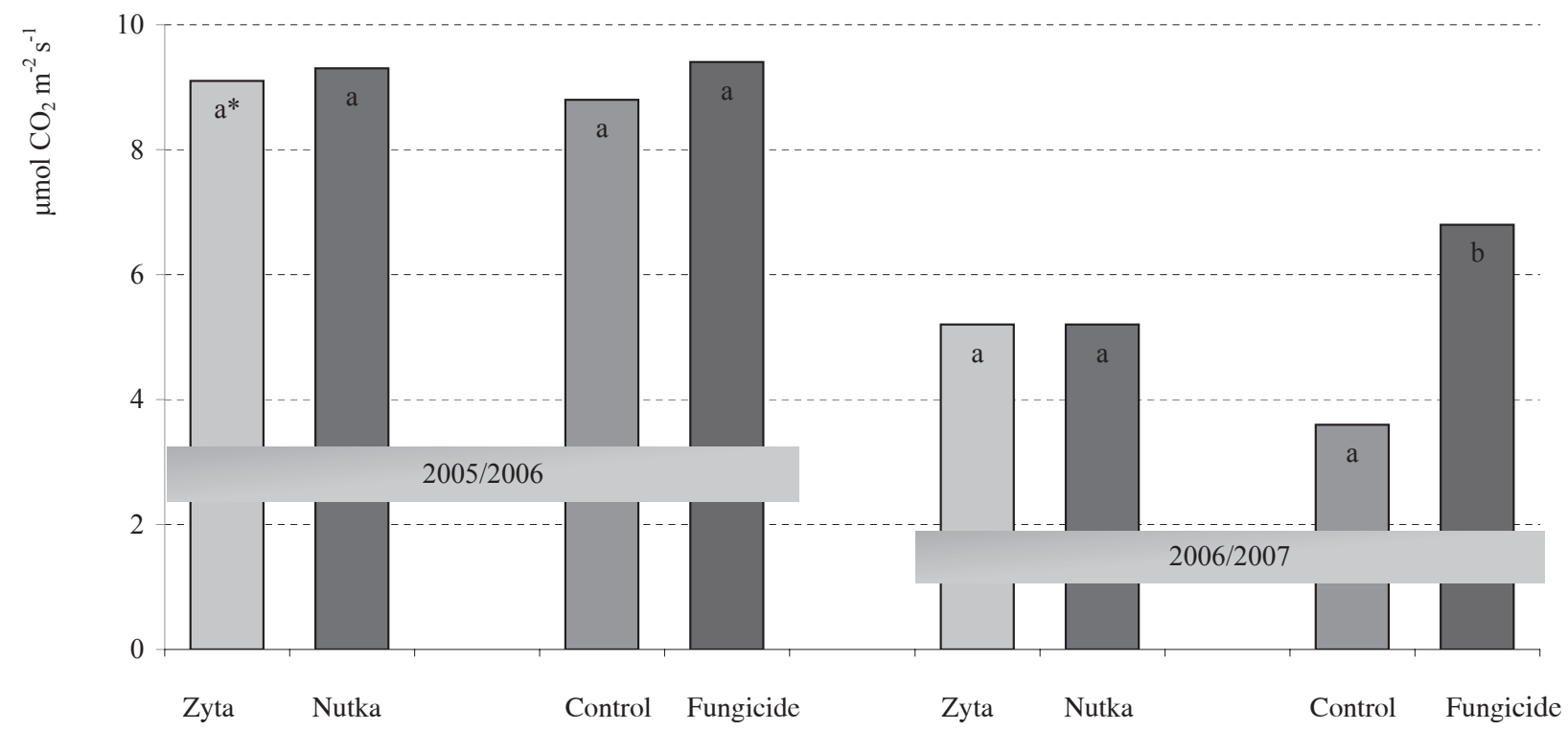

* homogenous groups according to Fisher's LSD test $(\alpha=0.05)$

Fig. 5. Winter wheat leaf photosynthesis 35 days after application of the fungicide Juwel (heading stage BBCH 51-53)

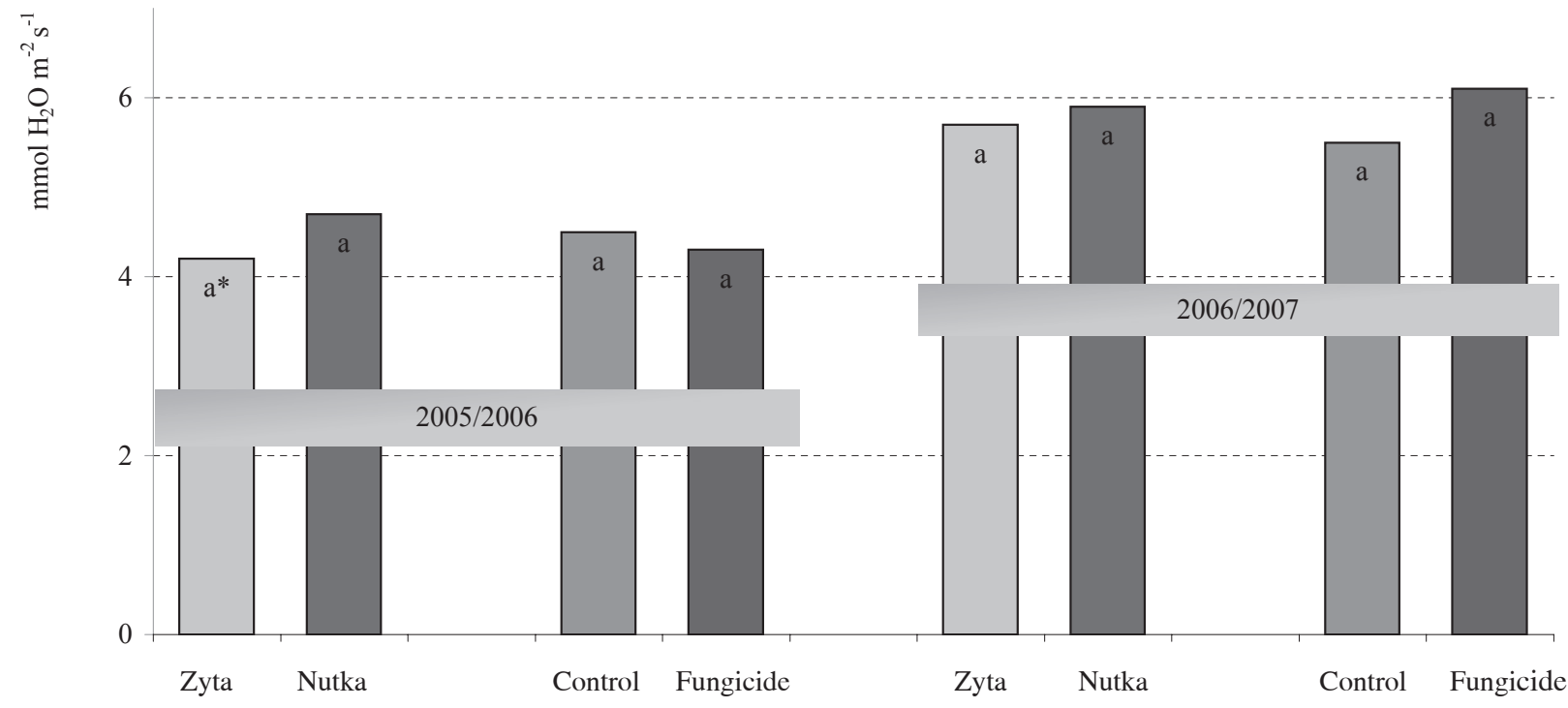

* homogenous groups according to Fisher's LSD test $(\alpha=0.05)$

Fig. 6. Winter wheat leaf transpiration 35 days after application of the fungicide Juwel (heading stage BBCH 51-53) 


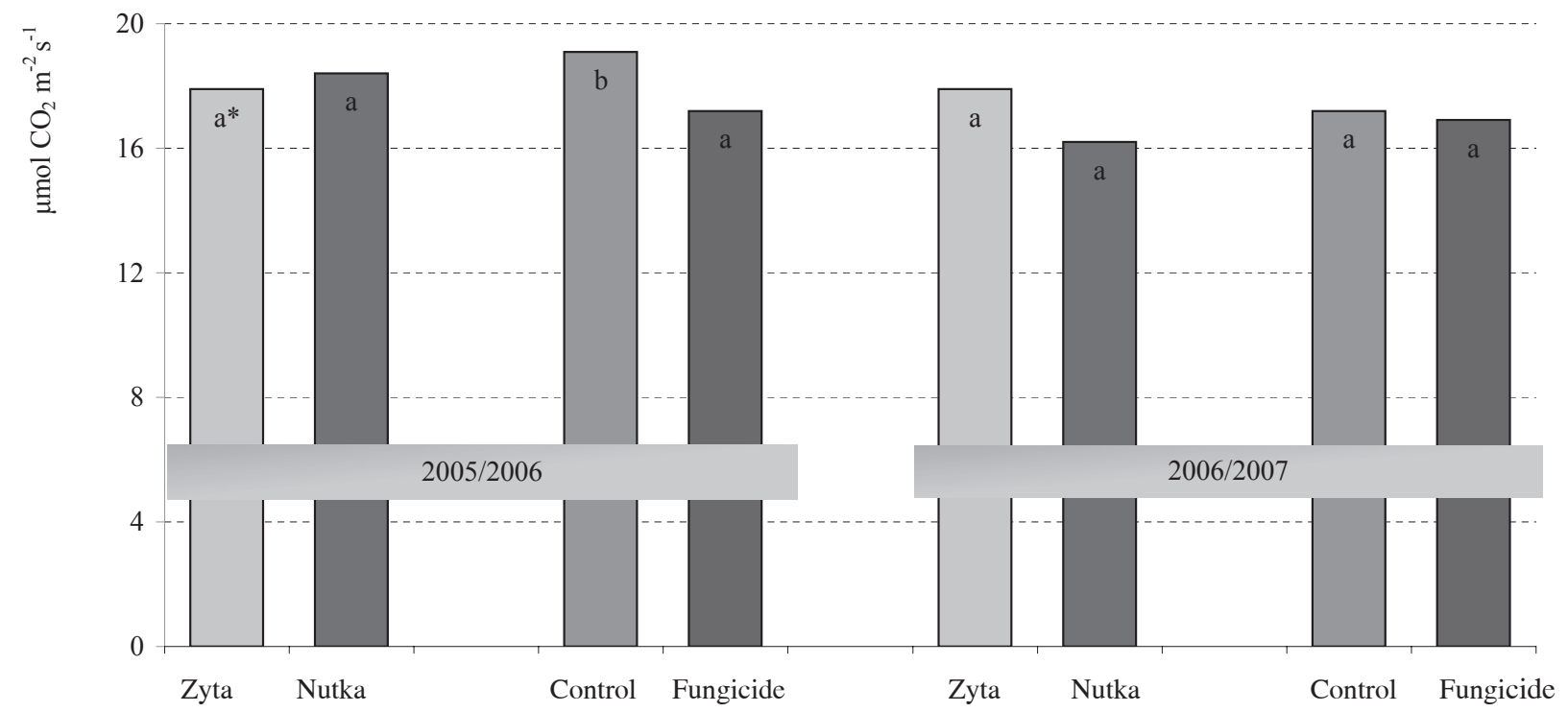

* homogenous groups according to Fisher's LSD test $(\alpha=0.05)$

Fig. 7. Winter wheat leaf photosynthesis 7 days after application of the fungicide Swing (heading stage BBCH 57-59)

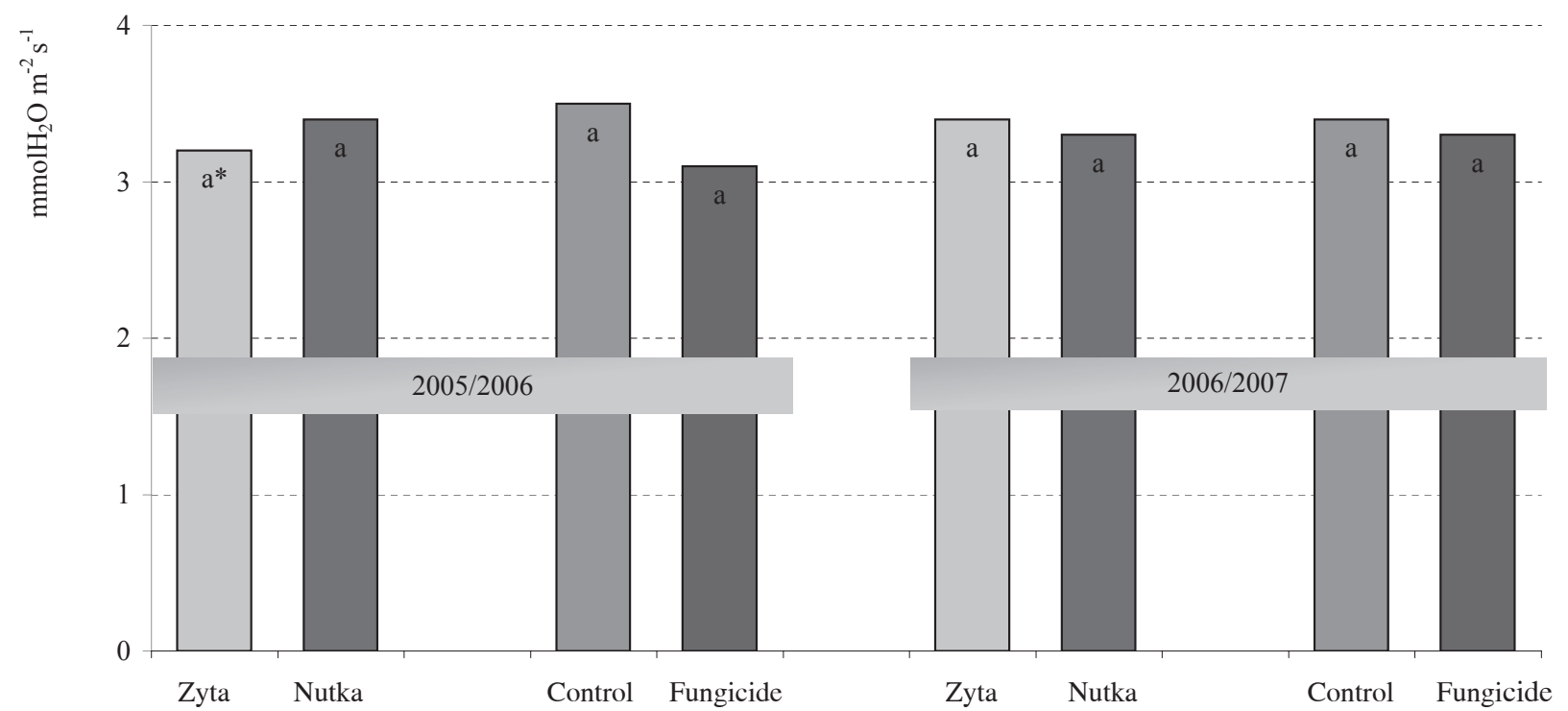

* homogenous groups according to Fisher's LSD test $(\alpha=0.05)$

Fig. 8. Winter wheat leaf transpiration 7 days after application of the fungicide Swing (heading stage BBCH 57-59) 


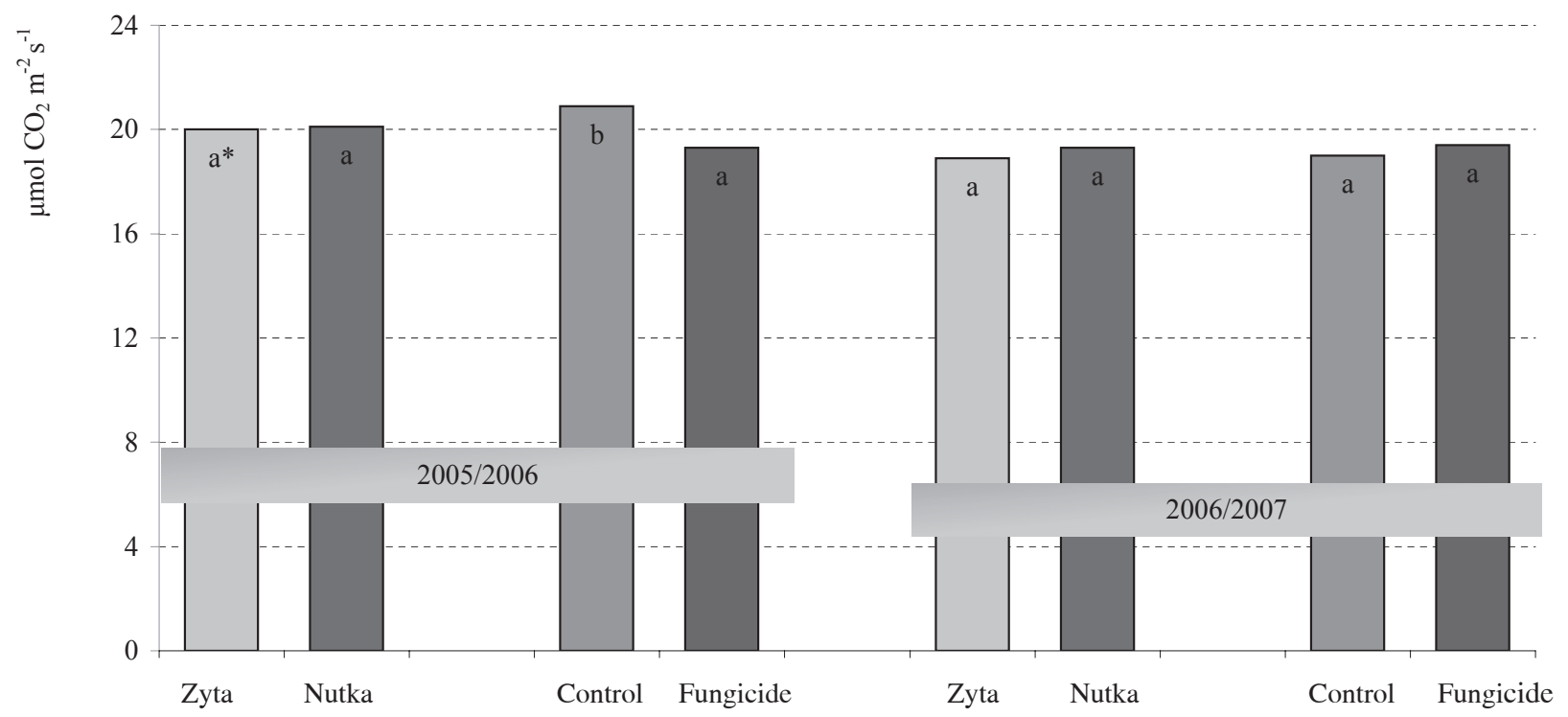

* homogenous groups according to Fisher's LSD test $(\alpha=0.05)$

Fig. 9. Winter wheat leaf photosynthesis 21 days after application of the fungicide Swing (flowering stage BBCH 69-71)

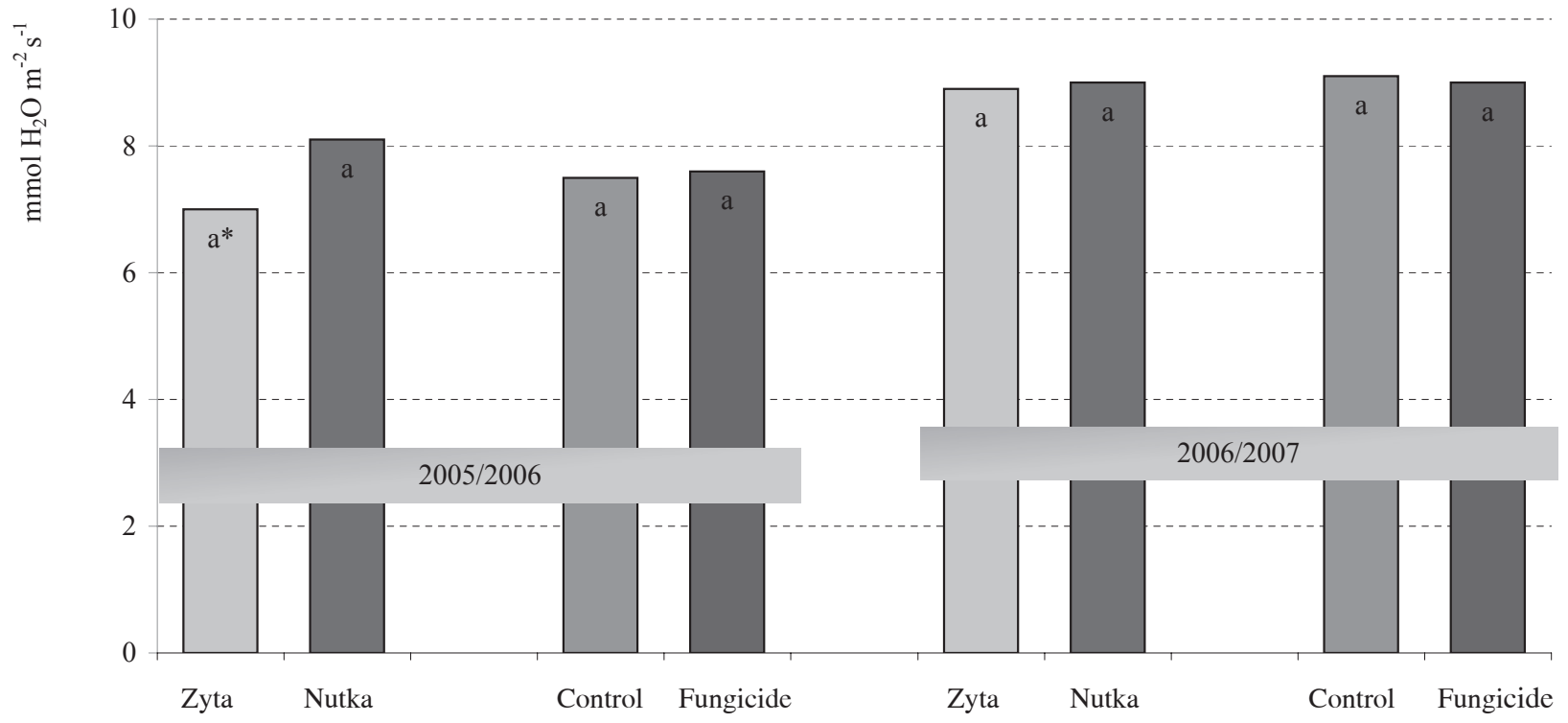

* homogenous groups according to Fisher's LSD test $(\alpha=0.05)$

Fig. 10. Winter wheat leaf transpiration 21 days after application of the fungicide Swing (flowering stage BBCH 69-71) 


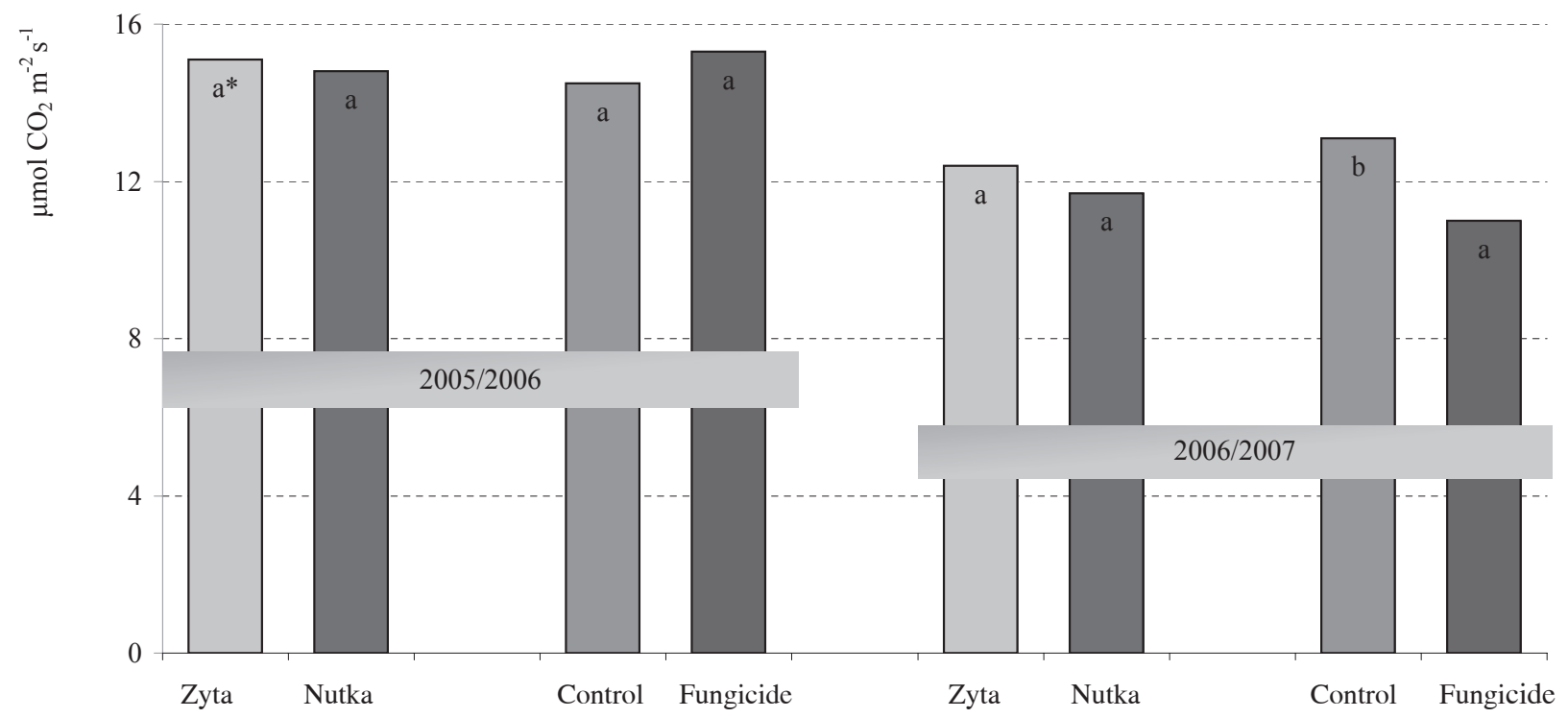

* homogenous groups according to Fisher's LSD test $(\alpha=0.05)$

Fig. 11. Winter wheat ear photosynthesis 5 days after application of the fungicide Swing (heading stage BBCH 57-58)

Zyta Nutka Control Fungicide Zyta Nutka Control Fungicide

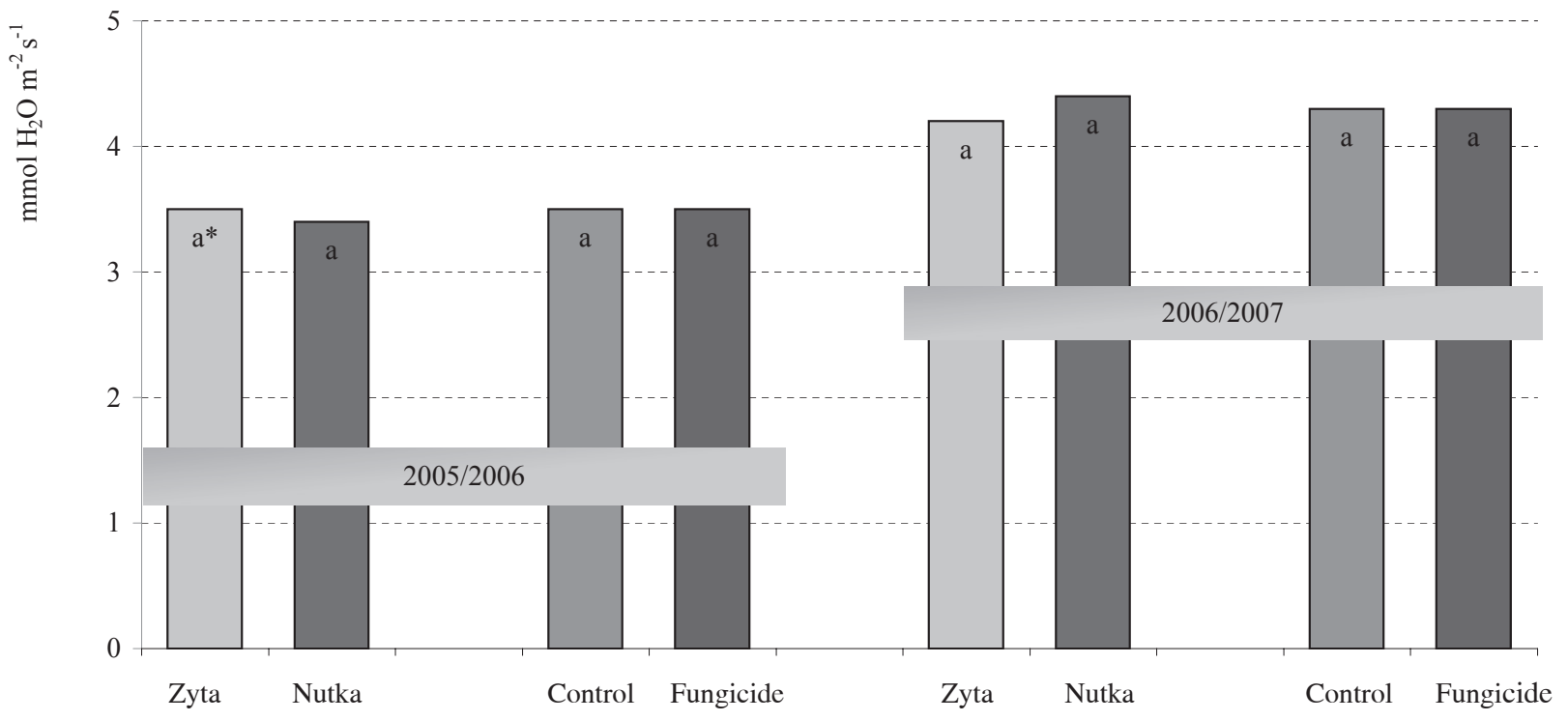

* homogenous groups according to Fisher's LSD test $(\alpha=0.05)$

Fig. 12. Winter wheat ear transpiration 5 days after application of the fungicide Swing (heading stage BBCH 57-58) 


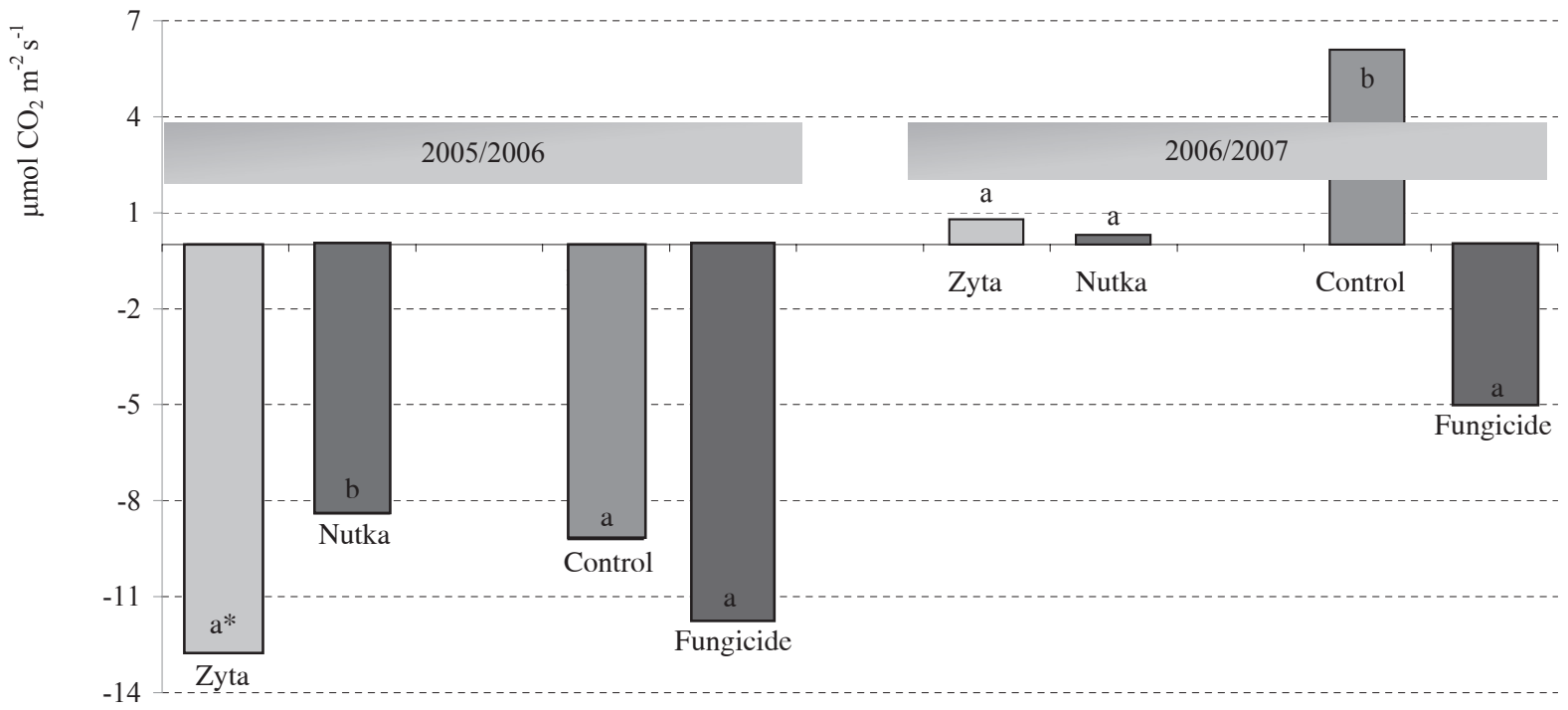

* homogenous groups according to Fisher's LSD test $(\alpha=0.05)$

Fig. 13. Winter wheat ear photosynthesis after application of the fungicide Swing (milk ripe stage BBCH 71-73, year 2005/06; watery ripe stage BBCH 67-69, year 2006/07)

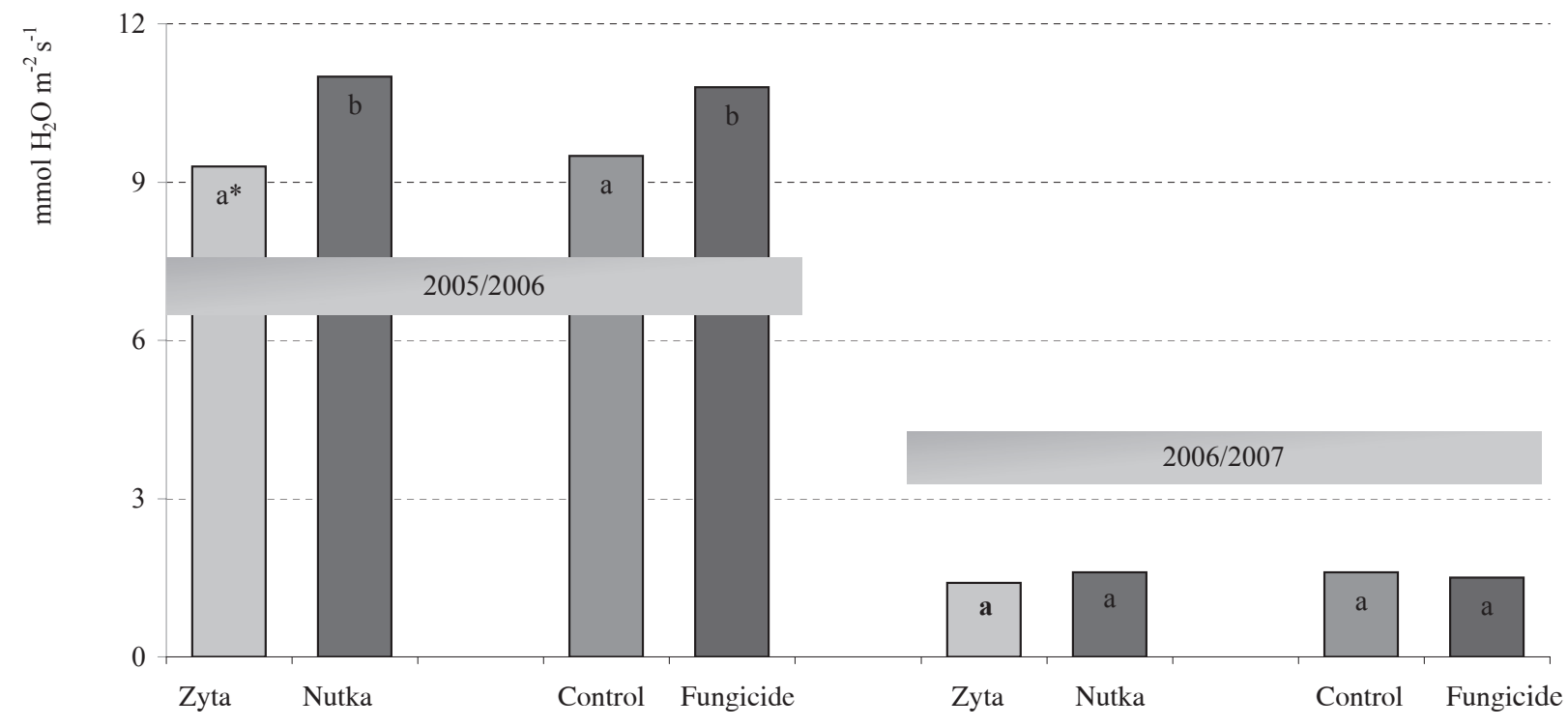

* homogenous groups according to Fisher's LSD test $(\alpha=0.05)$

Fig. 14. Winter wheat ear transpiration after application of the fungicide Swing (milk ripe stage BBCH 71-73, year 2005/06; watery ripe stage $\mathrm{BBCH}$ 67-69, year 2006/07) 


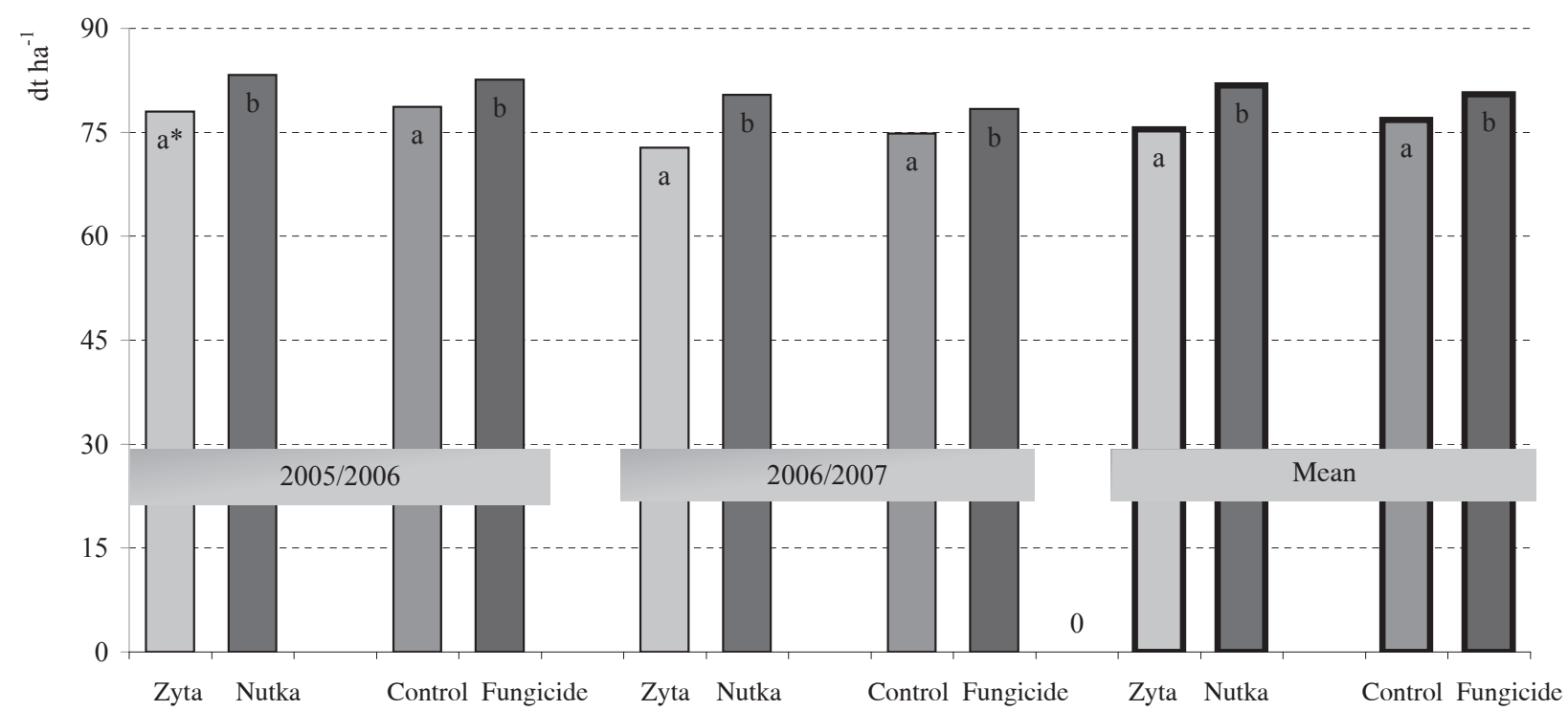

* homogenous groups according to Fisher's LSD test $(\alpha=0.05)$

Fig. 15. Winter wheat grain yield

ing influence on the level of photosynthesis. An earlier study of O 1 s z e w s k i (2004) did not confirm the negative effects of fungicides on the photosynthetic apparatus. However, there was observed a tendency towards a slight decrease in the rate of photosynthesis under the influence of a fungicidal agent. Furthermore, the abovementioned author found a significant decline in the levels of photosynthesis and transpiration under the effect of foliar herbicide application.

Under conditions of reduced photosynthetic activity of leaves, their role is taken over by ears. Some researchers (Evans et al. 1972; Johnson and Mos s, 1976; B l u m, 1985) even claim that under stress conditions ears play a more important role in carrying out photosynthesis than flag leaves. The study conducted by O 1 s ze w s ki et al. (2008) showed that in these organs there was higher release of $\mathrm{CO}_{2}$ into the atmosphere than its assimilation. This phenomenon occurs during the daytime with the participation of photosynthetically active radiation (PAR) (K l e c z k ow $\mathrm{ski}$ et al. 1988). In the opinion of other researchers (N a l b o r c z y k, 1993; S ta r c k, 2002), the proportion of organs other than leaves in total photosynthesis ranges from several to a dozen or so percent.

Our own study showed a high level of photosynthesis in ears at the initial stage of their development. Next measurements exhibited a systematic decline in photosynthetic activity of these organs, being larger in the treatments in which the fungicides had been applied. The study of $\mathrm{N}$ a s o n et al. (2007) showed a decrease in the rates of photosynthesis and transpiration, among others, as a result of the application of fungi- cides in which strobilurins were the active substance. But no such correlation was demonstrated in the case of the application of triazoles or epoxiconazole.

In their investigations of the rate of photosynthesis in leaves and ears of wheat grown under water deficit conditions, I n o u e et al. (2004) obtained negative values for this parameter. The study of $\mathrm{O} 1 \mathrm{~s} \mathrm{z} \mathrm{e} \mathrm{w} \mathrm{-}$ ski et al. (2008) also demonstrated in wheat ears higher $\mathrm{CO}_{2}$ release into the atmosphere than its uptake. Similarly in the experiment of $\mathrm{W}$ ang et al. (2001), photosynthesis of winter wheat ears had negative values on the 28th day after the beginning of flowering. Besides, in the case of leaf blades the values of this parameter were higher than they were for other green organs. According to S t a r c k (2002), the process of photosynthesis occurs in all green organs (also in ears), but with much lower intensity than in leaves.

In the present study, the applied fungicides modified only ear length and 1000 grain weight (TGW). Similar results were obtained by $\mathrm{P} \mathrm{s}$ z c z ó $ł$ k o w s k a (2008) who found a significant effect of fungicides on TGW relative to the control treatment. This author reports that the highest TGW was obtained after the application of the fungicides Juwel and Swing.

Both in the first and second year of the experiment, wheat grain yield was relatively high and the fungicides applied significantly increased its level. Bertelsen et al. (2001), Ruske et al. (2004) as well as P s z c zółk ow s ka (2008) obtained similar results in their studies; they reported an increase in winter wheat grain yield in all fungicide treatments. 


\section{CONCLUSIONS}

1. Among the fungicides applied, only Swing Top 183 SC showed a negative effect on the process of photosynthesis in leaves, reducing the value of the measured parameter. But the other of the fungicidal agents did not differentiate the level of photosynthesis.

2. At the heading stage, photosynthesis measured as the rate of $\mathrm{CO}_{2}$ assimilation occurred in ears with great intensity, whereas the fungicides used resulted in higher release of $\mathrm{CO}_{2}$ than its uptake. Moreover, at the watery ripe stage the level of ear photosynthesis significantly decreased.

3 . The applied fungicides significantly increased grain yield relative to the control, both in the first and second year of the study. In addition, 'Nutka' was characterized by higher yield, in spite of lower 1000 kernel weight. This cultivar developed significantly longer ears with a larger amount of grains.

\section{REFERENCES}

Bertelsen J. R., de Neergaard E., Smedegaard - Petersen V., 2001. Fungicidal effects of azoxystrobin and epoxiconazole on phyllosphere fungi, senescence and yield of winter wheat. Plant Pathology, 50; 190-205.

Blu m A., 1985. Photosynthesis and transpiration in leaves and ears of wheat and barley varieties. J. Exp. Bot. 36: 432440.

Evans L. T., Bingham J., Jacks on P., Sutherland J., 1972. Effect of awns and drought on the supply of photosynthate and its distribution within wheat ears. Ann. Appl. Biol. 70: 67-76.

Frisvad J. C., Andersen B., Thrane U., 2008. The use of secondary metabolite profiling in chemotaxonomy of filamentous fungi. Mycological Research, 112: 231-240.

Grzesiuk S., Koczowska I., Górecki R. J., 1999. Fizjologiczne podstawy odporności roślin na choroby. I The physiological basis for plant resistance to diseases. Wyd. II. ART Olsztyn (in Polish).

Hurey M., Śn ieżko R., 1986. Wpływ wybranych pestycydów na fotosyntezę i plon roślin chronionych. / The effect of some pesticides on photosynthesis and yield of protected plants. Post. Nauk Roln. 4: 51-62 (in Polish).

Inoue T., In anaga S., Sugimoto Y., An P., Eneji A. E., 2004. Effect of drought on ear and flag leaf photosynthesis of two wheat cultivars differing in drought resistance. Photosynthetica, 42 (4): 559-565

John s on R. R., Mos s D. N., 1976. Effect of water stress on $14 \mathrm{CO}_{2}$ fixation and translocation in wheat during grain filling. Crop Sci. 16: 697-701.

Kleczkowski L., Łoboda T., Nalborczyk E., 1988. Pomiary fotooddychania u roślin wyższych. / Phototranspiration measurements in higher plants. Wiad. Bot. 32 (4): 227-240 (in Polish).
Na lborcz y k E., 1993. Biologiczne uwarunkowania produktywności roślin strączkowych. / Biological conditions for the productivity of leguminous plants. Fragmenta Agronomica, 4: 147-150 (in Polish).

Nas on M. A., Farrar J., Bartlett D., 2007. Strobilurin fungicides induce changes in photosynthetic gas exchange that do not improve water use efficiency of plants grown under conditions of water stress. Pest Management Sci. 63: 1191-1200.

Nielsen K. F., S medsga ard J., 2003. Fungal metabolite screening: database of 474 mycotoxins and fungal metabolites for dereplication by standarised liquid chromatography - UV - mass spectrometry methodology. J. Chromat. A, 1002: 111-136.

Olszewski J., 2004. Wpływ wybranych stresów abiotycznych i biotycznych na intensywność fotosyntezy i transpiracji, plonowanie oraz zdrowotność bobiku i grochu siewnego. / The effect of some biotic and abiotic stresses on the rate of photosynthesis and transpiration, yield and health of horse bean and pea. Rozprawy i Monografie 85. Wydawnictwo UWM. Olsztyn (in Polish).

Olszewski J., Pszczółkowska A., Kulik T., Fordoński G., Płodzień K., Okorski A., Wasielewska J., 2008. Rate of photosynthesis and transpiration of winter wheat leaves and ears under water deficit conditions. Polish J. Natur. Sci. 23 (2): 326-335.

Pszczółkowska A., 2008. Diagnostyka patogenów grzybowych metodą PCR i tradycyjną oraz produkcyjność pszenicy ozimej (Triticum aestivum L.) w warunkach zróżnicowanej ochrony fungicydowej. / Diagnostics of fungal pathogens using PCR and the traditional method as well as winter wheat (Triticum aestivum L.) productivity under different conditions of fungicide control. Rozprawy i Monografie 140. Wydawnictwo UWM. Olsztyn (in Polish).

Rożek S., Wnuk A., 1994. Wpływ wybranych pestycydów na zawartość niektórych składników w nasionach i w kiełkach dwóch odmian bobiku. / The effect of selected pesticides on the content of some nutrients in seeds and sprouts of two horse bean varieties. Acta Agr. Silv. 32: 75-83 (in Polish).

Ruske R. E., Gooding M. J., Dobraszczyk B. J., 2004. Effects of triazole and strobilurin fungicide programmes, with and without late - season nitrogen fertiliser, on the baking quality of Malacca winter wheat. J. Cereal Sci. 40: 1-8.

Starck Z., 2002. Fizjologia roślin. Red. J. Kopcewicz, S. Lewak. Wyd. Nauk. Państwowe Wydawnictwo Naukowe, Warszawa (in Polish).

Wang Z.-M., Wei A.-L., Zheng D.-M., 2001. Photosynthetic characteristics of non-leaf organs of winter wheat cultivars differing in ear type and their relationship with grain mass per ear. Photosynthetica, 39: 239-244. 


\section{Wskaźniki wymiany gazowej liści i kłosów oraz produkcyjność pszenicy ozimej (Triticum aestivum L.) w warunkach ochrony fungicydowej}

\section{Streszczenie}

Przeprowadzono eksperyment badawczy, w którym mierzono intensywność fotosyntezy i transpiracji w liściach i kłosach dwóch odmian pszenicy ozimej uprawianej w warunkach ochrony fungicydowej oraz bez ochrony. W analizach posłużono się przenośnym analizatorem gazowym LI-COR 6400. Wykazano, że fungicyd Juwell w większości przypadków nie miał wpływu na przebieg wskaźników wymiany gazowej, natomiast drugi ze stosowanych preparatów - Swing, znacząco obniżał intensywność mierzonych procesów.
Pomiary wskaźników wymiany gazowej kłosów wykazały, że proces ten zachodził w niewielkim nasileniu, zwłaszcza w późniejszej fazie rozwojowej kłosów. Natomiast zastosowany fungicyd spowodował wyższe wydzielanie $\mathrm{CO}_{2}$ do atmosfery, niż jego pobieranie. Ponadto stwierdzono, że aplikowane preparaty istotnie zwiększyły plon ziarna w stosunku do kontroli, zarówno w pierwszym, jak i drugim roku badań.

Spośród testowanych odmian Nutka charakteryzowała się wyższym plonowaniem, pomimo mniejszej masy tysiąca ziarniaków. Jednak odmiana ta wykształciła istotnie dłuższe kłosy, o większej liczbie ziaren. 
